\title{
Evaluation of Industrial Processes to Obtain Chitin and Chitosan
}

\author{
Marinela Colina, $\mathrm{PhD}^{1,2,3}$, José Alejandro Vargas Colina, BSc ${ }^{2,3}$, José Alejandro Molina Zerpa, MSc,3, José Antonio \\ Vargas Bianchi ${ }^{3}$, Carlos Rodríguez-Monroy, $\mathrm{PhD}^{4}$, Moisés Enrique Martínez-Soto, $\mathrm{PhD}^{5}$.
}

\author{
${ }^{1}$ Universidad del Zulia, Facultad Experimental de Ciencias, Maracaibo 4011. Zulia. Venezuela. colinamarinela@gmail.com \\ ${ }^{2}$ Empresa Innovación Ambiental Quitosano CA. Av. San Francisco, Maracaibo Estado Zulia. Venezuela \\ ${ }^{3}$ Inbiotech Corporation SA. Chiriqui. República de Panamá \\ ${ }^{4}$ Universidad Politécnica de Madrid, Escuela Técnica Superior de Ingenieros Industriales, Madrid, España \\ ${ }^{5}$ Universidad del Zulia-INSTGECON, Facultad de Agronomía, Maracaibo 4001, Venezuela
}

\begin{abstract}
In this research, the operational conditions for the industrial chemical processes to obtain chitin and chitosan are analyzed. The obtention of chitosan was performed using crab wastes from the industry using the exoskeleton of blue crab (Callinectes sapidus). The four main steps for obtaining chitosan were: deproteinization with $\mathrm{NaOH} 10 \%$, demineralization using two acids (hydrochloric acid and phosphoric acid) of two different concentrations with reaction time variations to determine the more acceptable acid for the remotion of minerals, decoloration using sunlight irradiation and as final step thermoalcaline hydrolysis of chitin with $30 \%$ $\mathrm{NaOH}$. The chitosan obtained was characterized by FTIR where the bands of the functional groups characteristics for chitosan were observed, the amine group band at 1,621 and 1,650 cm-1, the acetamide group (amide I). Chitosan with degree of deacetylation berween 82.52 and $95.01 \%$ was obtained calculated by Fourier Infrared Transformed. Additionally, percentage of ashes and humidity were measured. Industrial chitosan was obtained with high viscosity, high molecular mass and high degree of deacetylation with this treatment.
\end{abstract}

\section{process}

Keywords: chitin, chitosan, pilot reactor, obtention

\section{INTRODUCTION}

The extraction techniques to obtain chitin and chitosan found in the literature are very diverse, since they depend to a great extent on the characteristics of the source. The composition of the starting material varies considerably from one species to another. Most of the techniques developed rely on chemical processes of protein hydrolysis and the removal of inorganic matter. Some include a decoloration step of the extracted chitin, by means of a solvent extraction, the oxidation of the remaining pigments or the sun. To obtain chitosan an additional step of deacetylation is needed [1-7].

Conditioning of the raw material. It consists in the washing with water of the shells to be processed and separation of the mass that may remain attached to them. Subsequently, it is

Digital Object Identifier (DOI): http://dx.doi.org/10.18687/LACCEI2018.1.1.408 ISBN: 978-0-9993443-1-6

ISSN: $2414-6390$ grinded to the appropriate particle size for extraction, which is usually several millimeters

Deproteinization. The most commonly used procedure to deproteinize is to treat the shells of crustaceans with a dilute aqueous solution of $\mathrm{NaOH}$ at rather high temperature (65-100 ${ }^{\circ} \mathrm{C}$ ), in order to dissolve the protein. The treatment time usually varies between 0.5 and 72 hours. Sometimes it is preferred to perform two consecutive treatments for short periods. It must be kept in mind that treatments for a long time or at very high temperatures can cause chain rupture and partial deacetylation of the polymer. Other agents have also been used to extract the protein, among which the following are mentioned: $\mathrm{Na}_{2} \mathrm{CO}_{3}$, $\mathrm{NaHCO}_{3}, \mathrm{KOH}, \mathrm{K}_{2} \mathrm{CO}_{3}, \mathrm{Ca}(\mathrm{OH})_{2}, \mathrm{Na}_{2} \mathrm{SO}_{3}, \mathrm{NaHSO}_{3}, \mathrm{Na}_{3} \mathrm{PO}_{4}$ and $\mathrm{Na}_{2} \mathrm{~S}[8]$.

The processes of deproteinization using enzymatic extracts or isolated enzymes and microbiological fermentations have been tested with relative success, but the alternative of enzymatic/microbiological treatment, besides consuming a long time, usually leaves 1-7\% of residual protein.

Demineralization The main inorganic component of the shell of crustaceans is $\mathrm{CaCO}_{3}$, which is usually eliminated using diluted solutions of $\mathrm{HCl}$ (up to 10\%) at room temperature, although other acids $\left(\mathrm{HNO}_{3}, \mathrm{HCOOH}, \mathrm{H}_{2} \mathrm{SO}_{4}\right.$, and $\left.\mathrm{CH}_{3} \mathrm{COOH}\right)$ can be used. The concentration of the acid and the time of treatment depend on the source, but treatments at higher temperatures, which cause the degradation of the polymer, should be avoided. An alternative treatment to reduce degradation consists of the use of the complexing agent EDTA (ethylenediaminetetraacetic acid) [ 9-10].

There are also studies of lactic fermentation which involve the use of lactic acid bacteria (Lactobacillus) for the deproteinization and decalcification of the material, obtaining chitin as the final product

Decoloration The coloration of crustacean shells is mainly due to the presence of pigments such as astaxanthin, canthaxanthin, astacene, lutein and $\beta$-carotene. The above treatments are generally not able to remove these pigments, which are usually extracted at room temperature with acetone, chloroform, ether, ethanol, ethyl acetate or solvent mixture [9]. Traditional oxidizing agents have also been used, such as $\mathrm{H}_{2} \mathrm{O}_{2}(0.5-3 \%)$ and $\mathrm{NaClO}(0.32 \%)$, although it should be noted that these

$16^{\text {th }}$ LACCEI International Multi-Conference for Engineering, Education, and Technology: "Innovation in Education and Inclusion”, 19-21 July 2018, Lima, Peru. 
usually attack the free amino groups and introduce modifications in the polymer. In highly colored carapaces, such as that of common lobster, the successful use of treatments with mixtures of acetone and $\mathrm{NaOCl}$ at room temperature has been reported [11]. Sun irradiation is also used in industrial processes.

Obtaining chitosan. The deacetylation of chitin is carried out by hydrolysis of the acetamide groups in strongly alkaline medium, at high temperatures. Generally, the reaction is carried out in a heterogeneous phase using concentrated solutions of $\mathrm{NaOH}$ or $\mathrm{KOH}(30-50 \%)$ at temperatures above $100{ }^{\circ} \mathrm{C}$, preferably in an inert atmosphere or in the presence of reducing substances such as $\mathrm{NaBH}_{4}$ or $\mathrm{Na}_{2} \mathrm{SO}_{3}$ to avoid depolymerization of the polymer. The specific conditions of the reaction will depend on various factors, such as the starting material, the pretreatment, and the desired degree of deacetylation[12-15].

Process for obtaining chitin and chitosan. To obtain chitin and chitosan crab exoskeletons of the variety (Callinectes sapidus) from Lake Maracaibo, Venezuela, were used. They were supplied from San Francisco Municipality of Zulia State. $5000 \mathrm{~kg}$ of wastes were collected which were milled to subsequently carry out the deproteinization by placing the sample in a reactor in which they were treated with a solution of $10 \% \mathrm{NaOH} \mathrm{m} / \mathrm{v}$ in a ratio of $1: 1(\mathrm{~m}: \mathrm{v})$ and $1 \%$ sodium sulfite as an antioxidant to prevent degradation of the material and heated to $100-110{ }^{\circ} \mathrm{C}$ during 60 minutes. After washing several times with abundant water, the wastes were dried at room temperature for 24 hours. This procedure was carried out in a reactor of $10.3 \mathrm{~m}^{3}$ (Figure 1). Moisture and ash were determined to the deproteinized ones obtained. Then the effectiveness of $\mathrm{HCl}$ and $\mathrm{H}_{3} \mathrm{PO}_{4}$ for the demineralization of chitin was evaluated, using different concentrations of molar acid $(1,2,3)$ with different reaction times (30 minutes, 1, 2, 3 and 4). The best demineralization step was evaluated by varying the solid / liquid ratio 1/3,1/5 and 1/7 at room temperature, to avoid degradation of the polymer. The amount of Ca that goes to solution was evaluated.

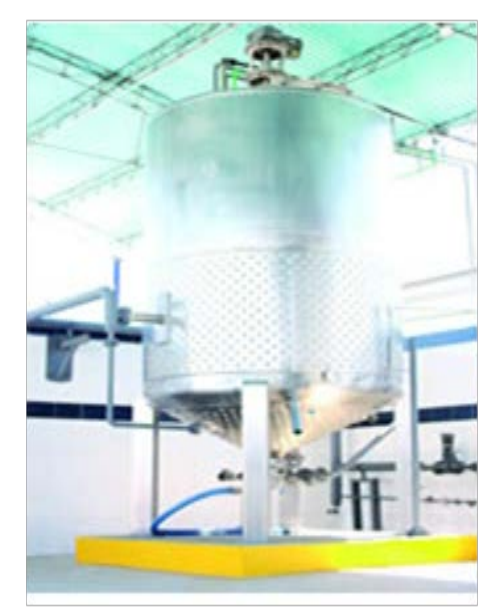

Figure 1: Reactor for the deproteinization process.

\section{RESULTS AND DISCUSSION}

Grinding. The particle size has an effect on the processes of deproteinization and demineralization. The size must be uniform and not greater than $0.5 \mathrm{~cm}$. Size greater than this, at the industrial level, affects the efficiency in these processes, requiring more alkali or acid. Very small particle sizes, less than $1 \mathrm{~mm}$, will produce chitosan powder that has better solubility properties. However, more chitosan is needed for the formation of a concentrated gel with acetic acid and resistant films.

Deproteinization. The first step in obtaining chitosan is the deproteinization of the crab wastes. In this stage the crab shells of the variety Callinectes Sapidus were treated with $\mathrm{NaOH}$ at high temperatures (approximately $110-115^{\circ} \mathrm{C}$ ) achieving denaturing the protein present. This occurs because the $\mathrm{NaOH}$ breaks the hydrogen bonds that hold together the protein molecules causing them to separate and disperse in the solution. The addition of an antioxidant such as $\mathrm{Na}_{2} \mathrm{SO}_{3}$ prevents the breakdown of the 1-4 glycosidic union of the polymer chains of chitin, which would produce the decrease in its molecular weight [16-20]. The effect of $\mathrm{NaOH}$ concentration and reaction time has been studied previously by members of our research group. López [21] found that in a time lapse between 0.5 and 1.5 hours, the highest efficiency in protein extraction is generated. When increasing the concentration of $\mathrm{NaOH}$ a greater protein concentration is obtained, however this increase is not very significant compared to the amount of total proteins obtained (see Table 1).

Table 1: Extraction of proteins from the crab shells at different concentrations of $\mathrm{NaOH}$ and at different times of reaction [21].

\begin{tabular}{|c|c|c|}
\hline $\begin{array}{c}\text { NaOH } \\
\text { concentrations } \\
\text { (M) }\end{array}$ & $\begin{array}{c}\text { Reaction time } \\
\text { (h) }\end{array}$ & $\begin{array}{c}\text { Protein } \\
\text { concentration } \\
\mathbf{( \mu g} / \mathbf{m L} \mathbf{)}\end{array}$ \\
\hline 0.5 & 0.5 & $4.333 \pm 23$ \\
& 1.0 & $4.660 \pm 32$ \\
& 1.5 & $4.720 \pm 29$ \\
\hline 1 & 0.5 & $4.470 \pm 28$ \\
& 1.0 & $4.670 \pm 31$ \\
& 1.5 & $4.866 \pm 27$ \\
\hline 1.5 & 0.5 & $4.513 \pm 32$ \\
& 1.0 & $4.990 \pm 29$ \\
& 1.5 & \\
\hline
\end{tabular}

In this process, several researchers have performed demineralization with different types of strong acids such as $\left(\mathrm{HCl}, \mathrm{HNO}_{3}, \mathrm{H}_{2} \mathrm{SO}_{4}\right)$ or weak $\left(\mathrm{CH}_{3} \mathrm{COOH}, \mathrm{HCOOH}\right)$ [22, 23]. No literature was found on the use of phosphoric acid. For this reason, in this investigation, demineralization was performed with this acid $\left(\mathrm{H}_{3} \mathrm{PO}_{4}\right)$, which could be an important source in the mass production of chitin on an industrial scale because it is a cheaper acid than hydrochloric acid and it is also easy to acquire because it has less control by chemical regulator organisms and can also release phosphates for agricultural uses. The strong acid ( $\mathrm{HCl})$ frequently used by most chitin researchers has also been used, since it has excellent results in 
the complete elimination of inorganic salts. López [21] found that the most abundant ions in the crabs' shells are $\mathrm{Ca}$ and $\mathrm{Mg}$ (Table 2). A correlation was found between the concentration of hydrochloric acid and the extraction efficiency of the minerals, with $\mathrm{R}=0.97$ for $\mathrm{Ca}$ and $\mathrm{R}=0.98$ for $\mathrm{Mg}$. Table 2 shows these results of mineral extraction using $\mathrm{HCl}$ at different concentrations and different reaction times. It can be seen that the reaction time slightly increases the concentration of the minerals by approximately $2 \%$. This at the industrial level is not significant so the time of 1 hour is enough for demineralization. With respect to the concentration of $\mathrm{HCl}$ it is observed that extraction increases by almost $100 \%$ when going from $1 \mathrm{M}$ to $2 \mathrm{M}$. For the $\mathrm{HCl}$ case, a concentration of $2 \mathrm{M}$ and a time of 2 hours is sufficient for a good extraction.

Table 2. Extraction of minerals from the crab shell at different times and acids.

\begin{tabular}{|c|c|c|c|c|c|c|}
\hline $\begin{array}{c}\text { Concentration } \\
\text { HCl (M) }\end{array}$ & $\begin{array}{c}\text { Time } \\
\boldsymbol{h}\end{array}$ & $\begin{array}{c}\mathrm{Ca} \\
\mathrm{mg} / \mathrm{Kg}\end{array}$ & $\begin{array}{c}\mathrm{Mg} \\
\mathrm{mg} / \mathrm{Kg}\end{array}$ & $\begin{array}{c}\mathrm{Na} \\
\mathrm{mg} / \mathrm{Kg}\end{array}$ & $\begin{array}{c}\mathrm{Sr} \\
\mathrm{mg} / \mathrm{Kg}\end{array}$ & $\begin{array}{c}\mathrm{K} \\
\mathrm{mg} / \mathrm{Kg}\end{array}$ \\
\hline 1 & 1 & 95.75 & 3513,5 & 1244 & 668,0 & 25,0 \\
& 2 & 98.50 & 3659.0 & 1248 & 656,5 & 25,8 \\
\hline 2 & 1 & 150.25 & 3.854 .5 & 1747 & 962,0 & 55,0 \\
& 2 & 153.6 & 3881.0 & 1704 & 972,5 & 56,0 \\
\hline
\end{tabular}

In the case of $\mathrm{H}_{3} \mathrm{PO}_{4}$ as shown in Figure 2, the variation of Ca concentration in the solution extracted from the deproteinized crab with phosphoric acid at different acid concentrations and at different reaction times is observed. It can be seen that after 30 minutes a good extraction is obtained for acid concentrations between 3 and $4 \mathrm{M}$. From there the calcium concentration begins to decrease. Industrially, at a concentration of $3 \mathrm{M}$ and 30 minutes a good extraction can be obtained.

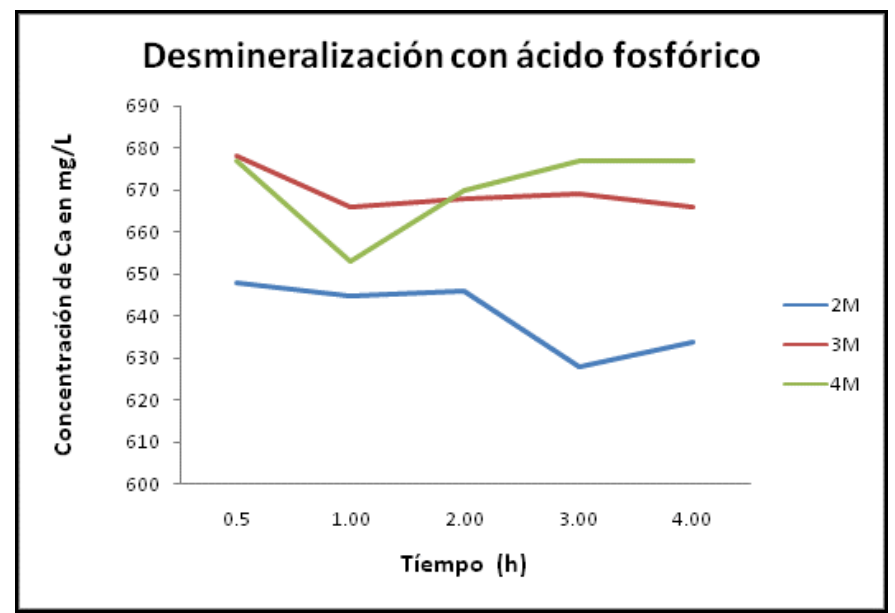

Figure 2. Extraction of calcium from the deproteinized crab using phosphoric acid at different concentrations and different reaction times.

Figure 3 shows how the calcium concentration in the demineralized solution varies when the solid / liquid ratio (deproteinized amount / phosphoric acid volume) is changed.
For a ratio $1 / 5(0.2)$ a good calcium extraction is obtained. For ratios larger than $1 / 7$ the amount of $\mathrm{Ca}$ extracted is already constant.

Once the solvent to be used has been selected, the effect of the solid/liquid ratio, stirring time, number of extractions and temperature in the extraction of the pigments was studied. In Figure 4, the results obtained in terms of extraction performance are exposed to the different solid/liquid ratios used

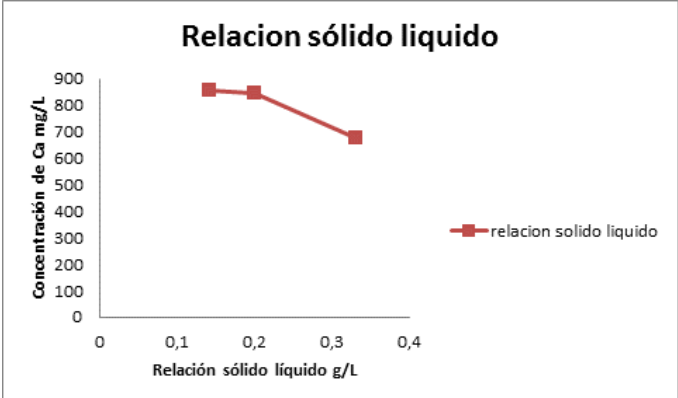

Figure 3: The calcium concentration in the demineralized solution varying the solid/liquid ratio.

As observed, the highest extraction yield was obtained when the ratio 0.1333 (20 g / $150 \mathrm{~mL}$ ) was used. As expected, when a smaller volume of the extractant is used for the same amount of sample, the extraction efficiency is lower.

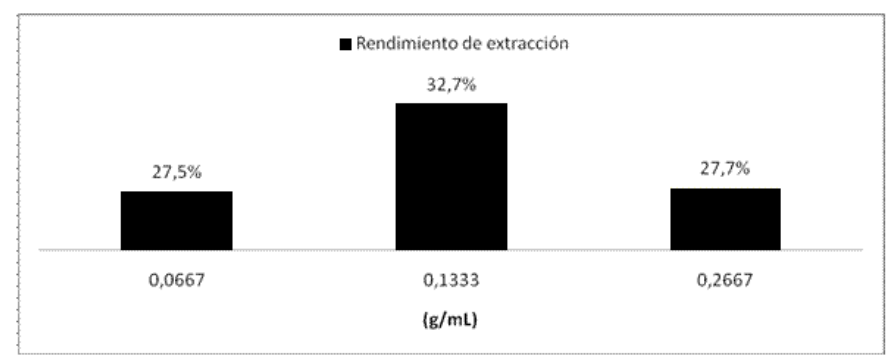

Figura 4. Efect of the solid/liquid relation on the extraction of pigments.

Regarding the influence of time on the extraction performance of the pigments, the following was obtained: From the results obtained, it is clear that there is a correlation between the stirring time and the efficiency of the extraction, the value of $\mathrm{R}$ being equal to 0.9975 . However, because the increase in stirring time is not directly proportional to the increase in extraction yield, 1 hour was selected as the optimum agitation time. In addition, it is worth mentioning that there is the possibility that at times of agitation greater than 6 hours, other components present in the shells could be dissolving. Figure 5 shows the results obtained in the experiments of successive extractions of 1 hour. 


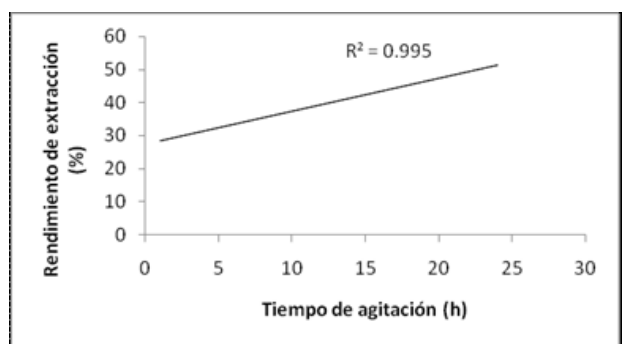

Figure 5. Influence of the agitation time in the extraction of pigments

\section{Characterization of chitin by infrared spectroscopy with Fourier Transform.}

Figure 6 shows the infrared spectra of the chitins obtained with the different acids, in which the typical infrared signals of chitin can be distinguished, such as the vibration signal - $\mathrm{OH}$ at 3,600$3,500 \mathrm{~cm}^{-1}$, the bands of amide I and II at 1650 and $1550 \mathrm{~cm}^{-1}$ corresponding to chitin, bands corresponding to the pigments present in the sample are also observed, which present functional groups $\mathrm{C}=\mathrm{C}$ in $1650 \mathrm{~cm}^{-1}$ in addition to the elongations of the band at 2,923 $\mathrm{cm}^{-1}$. The bands between 898 and $1156 \mathrm{~cm}^{-1}$ represent the structures of polysaccharides [1418]. At the same figure, the Sigma-Aldrich commercial chitin spectrum is shown, where the same functional groups of the obtained chitins are appreciated, which confirms that the product obtained after deproteinization and demineralization is chitin.

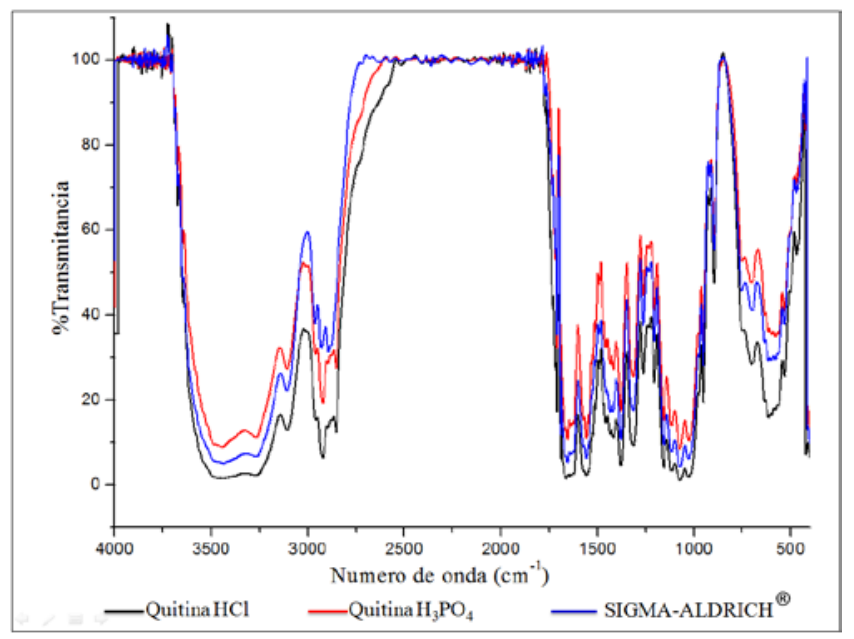

Figura 6. Chitin FTIR spectra compared with Comercial Sigma-Aldrich Chitin, and two acids hydrocholire and phosphoric acid.

Deacetylation of chitin. The reaction of N-deacetylation of chitin with sodium hydroxide, occurs with a hydrolysis in which the hydroxide ion, strongly nucleophilic, attacked initially to the acetamide groups present in $C$ (2) by a nucleophilic addition-elimination mechanism, to generate the chitosan [25] (Figure 7).

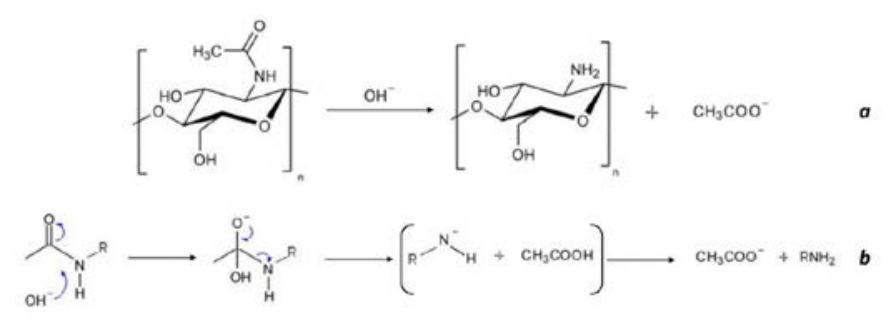

Figure 7. Mechanism of reaction of deacetylation of chitin to obtain chitosan. a) Generalized reaction, and b) Detail of the reaction mechanism

Deacetylation was carried out with a thermal treatment at high temperatures, due to the combination of three factors: 1) the low reactivity due to the trans-configuration of the acetamide substituents with respect to the $\mathrm{OH}$ group attached to the $\mathrm{C} 3$ atom of the pyranose ring of the unit monomeric [26], the presence of hydrogen bonds between the hydroxyl and carbonyl groups and amide of adjacent chains; and 3) the dense packing of the chains in the crystalline lattice of the chitin, which prevents the access of the alkali to the reactive sites.

The presence of oxygen during deacetylation influences the degradation of the polysaccharide and results in a decrease in the viscosity and molecular weight of the products. For this reason the addition of an antioxidant such as $\mathrm{Na}_{2} \mathrm{SO}_{3}$ was proposed, which prevents $\mathrm{NaOH}$ from reacting with hemiacetal groups, formed during demineralization by oxidizing them and forming carboxyl groups.

Physical-chemical characterization of chitosan. Table 3 shows the results obtained in the physico-chemical analysis of chitosan obtained from demineralized chitins with hydrochloric and phosphoric acids. The moisture content of the chitosan samples obtained from the demineralized chitins by hydrochloric and phosphoric acid showed significant differences $(\mathrm{p}<0.05)$.

The ash content is an indicator of the effectiveness of the demineralization process due to the elimination of the present minerals formed between 30-55\% constituted mainly by calcium carbonate $\left(\mathrm{CaCO}_{3}\right)$ and calcium phosphate, $\left(\mathrm{CaPO}_{4}\right)$, in minor proportion [27].

In Table 3 significant differences are observed $(\mathrm{p}<0.05)$, in the demineralization performed with the phosphoric acid during the concentrations of 1 and $2 \mathrm{M}$ at the reaction times there was no considerable variation in the ash content, at a concentration of $3 \mathrm{M}$, a greater mineral removal is evidenced in the different reaction times studied, showing significant differences between them ( $\mathrm{p}<0.05)$, obtaining an ash content of $5.50 \%$ for 50 minutes of reaction. On the other hand, the demineralization with hydrochloric acid considerably reduced the ash content, with no significant difference between them $(\mathrm{p}<0.05)$. It can be seen that the treatment carried out with hydrochloric acid at $2 \mathrm{M}$ and a reaction time of 50 minutes, presents an ash content of $1.99 \%$, which is within the accepted range for this type of products $(<2 \%$ ) food grade specified by several manufacturers. This treatment is considered as the most effective for the 
removal of minerals present in the exoskeleton although there is no significant difference to $(p<0.05)$ between this treatment and those of $3 \mathrm{M}$ in the different reaction times studied, since the demineralization treatment should avoid high concentrations of acid due to the possibility of degradation of chitin by breaking the 1-4 glycosidic bonds. This occurs when the etheric union 1-4 is protonated, causing the acetal group in C (1), to collapse forming a hemiacetal which divides the polymeric molecule, this does not allow the demineralization process to be carried out with $\mathrm{pH}$ values lower than 3 , so this acid concentration is not suitable for demineralization.

Table 3. Ash and moisture content of the chitosan obtained from deacetylation of demineralized chitin samples with hydrochloric acid and phosphoric acid at the different reaction conditions.

\begin{tabular}{|c|c|c|c|c|c|}
\hline $\begin{array}{c}\text { Concentration } \\
M\end{array}$ & $\begin{array}{c}\text { Time } \\
\min \end{array}$ & $\begin{array}{c}\text { Humidity } \\
\mathrm{HCl} \\
\%\end{array}$ & $\begin{array}{c}\text { Ash } \\
\mathrm{HCl} \\
\%\end{array}$ & $\begin{array}{c}\text { Humidity } \\
\mathrm{H}_{3} \mathrm{PO}_{4} \\
\%\end{array}$ & $\begin{array}{c}\text { Ash } \\
\mathrm{H}_{3} \mathrm{PO}_{4} \\
\%\end{array}$ \\
\hline 1 & 30 & 13.2 & 4.5 & 1.3 & 61 \\
& 40 & 7.5 & 4.7 & 2.8 & 69 \\
& 50 & 7.5 & 4.0 & 2.3 & 53 \\
\hline 2 & 30 & 7.5 & 2.9 & 2.3 & 32 \\
& 40 & 7.2 & 2.0 & 9.0 & 26 \\
& 50 & 8.4 & 1.9 & 5.3 & 25 \\
\hline 3 & 30 & 7.5 & 1.9 & 6.2 & 12.5 \\
& 40 & 6.8 & 1.9 & 7.0 & 7.0 \\
& 50 & 8.3 & 1.9 & 7.6 & 5.0 \\
\hline
\end{tabular}

Characterization of chitosan by infrared spectroscopy with Fourier Transform.

In Figure 8 the FTIR spectrum of the chitosan obtained by means of the partial deacetylation of the demineralized chitins with hydrochloric acid and phosphoric acid can be observed. The bands of the functional groups characteristic of the chitosan molecule can be observed, evidencing the appearance of the band of the amino group at $1621 \mathrm{~cm}^{-1}$ and a better definition of the bands of the $\mathrm{OH}$ groups is observed at 3,447 cm-1 and N-H at $3,258 \mathrm{~cm}^{-1}$, with respect to the chitin spectrum, due to the deacetylation process at $2,924 \mathrm{~cm}^{-1}$, the $\mathrm{C}$ - $\mathrm{H}$ stretch is evidenced, at $1,655 \mathrm{~cm}-1$ the voltage by vibration of the $\mathrm{C}=\mathrm{O}$ appears, at $1.571 \mathrm{~cm}^{-1}$ shows the torsional frequency -NH2, at $1423 \mathrm{~cm}-1$ the torsion $-\mathrm{CH}_{2^{-}}$, at $1.318 \mathrm{~cm}^{-1}$ the tension $\mathrm{C}-\mathrm{N}$, the symmetrical stretch C-O appears at $1.076 \mathrm{~cm}^{-1}$, and the C-O-C glucosidic stretch is seen at frequencies 895, 709 and $556 \mathrm{~cm}^{-1}$. Note how the signals corresponding to $\mathrm{C}-\mathrm{O}-\mathrm{C}, \mathrm{C}-\mathrm{H}$ and $\mathrm{OH}$, are present during all stages, while the bands corresponding to the $\mathrm{N}-\mathrm{H}$ group of the amine are better defined as the sample is subjected to each process chemical $[14,15]$. Regarding the bands found for both samples, they were consistent with the characteristics of commercial chitosan (Sigma-Aldrich) and corresponds to what was proposed by Hidalgo et al. [28,29]. The IR analysis showed the similarity in the spectra for each of the samples confirming with these results that the use of different chitins obtained by demineralization with $\mathrm{HCl}$ and $\mathrm{H}_{3} \mathrm{PO}_{4}$ did not affect the identity of the product, since the bands of the most important functional groups are maintained, thus demonstrating that the chitins were transformed into a new important raw material like chitosan

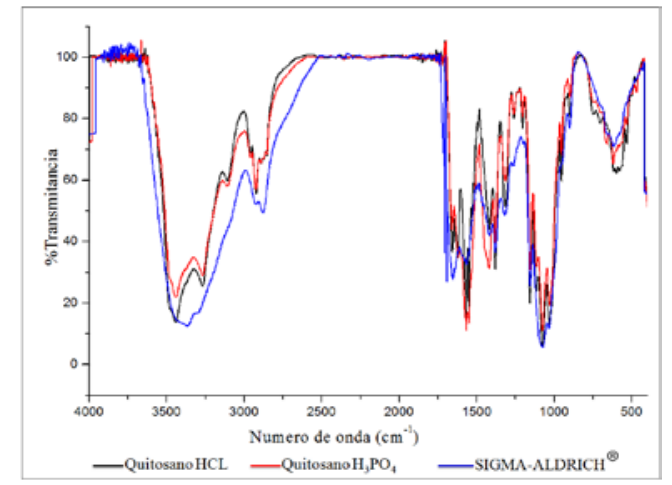

Figure 8: Chitosan FTIR spectra.

Degree of deacetylation. The degree of deacetylation calculated considering the absorbance of two standard bands of $(1,420 / 1,620)$ for the obtained chitosan samples are shown in Table 4.

The degree of deacetylation was determined by infrared Fourier transform spectrometry, using the equation proposed by Brugnerotto et al. [16], for the obtained chitosan samples are shown in Table 4. It is observed that the two factors studied have a significant influence on the degree of deacetylation of chitosan. The chitosans obtained from the N-deacetylation of demineralized chitins with hydrochloric acid showed degrees of deacetylation comprised (82.52-89.82\%), presenting a degree of deacetylation lower than those obtained by $\mathrm{N}$-deacetylation of demineralized chitins with phosphoric acid (91.09-95.01\%). On the other hand, the chitosan obtained by the N-deacetylation of the demineralized chitins with the phosphoric acid present greater intensity in the band at $2870 \mathrm{~cm}-1$, corresponding to the $\mathrm{C}-\mathrm{H}$ narrowing of the glucose ring; This band is sensitive to variations in the degree of deacetylation, an increase in the intensity of it is directly related to an increase in the degree of deacetylation. Similarly, the band at 3,291 cm -1 is more intense corresponding to the $\mathrm{N}-\mathrm{H}$ narrowing, sensitive to the degree of deacetylation [30].

Molecular weight. Table 4 also shows the molecular weights obtained by the capillary viscometry technique using the MarkHouwink-Sakurada equation [17]. The chitosans obtained from the N-deacetylation of the different demineralized chitins with the two acids showed significant differences at $(\mathrm{p}<0.05)$. The chitosans obtained by the $\mathrm{N}$-deacetylation of the demineralized chitins with the hydrochloric acid decrease gradually without presenting a pattern of apparent decrease, this is due to the increase in the concentrations of the acid used, discussed above.

$1^{\text {th }}$ LACCEI International Multi-Conference for Engineering, Education, and Technology: "Innovation in Education and Inclusion”, 19-21 July 2018, Lima, Peru. 
Table 4: Deacetylation degree and Molecular mass of the samples

\begin{tabular}{|c|c|c|c|c|c|}
\hline $\begin{array}{c}\text { Concentration } \\
\text { M }\end{array}$ & $\begin{array}{c}\text { Time } \\
\text { min }\end{array}$ & $\begin{array}{c}\text { DDA } \\
\% \\
\mathrm{HCl}\end{array}$ & $\begin{array}{c}\mathrm{Mv} \\
\mathbf{1 0 3} \\
\boldsymbol{g} \cdot \mathbf{m o l} \\
\mathbf{H C l}\end{array}$ & $\begin{array}{c}\text { DDA } \\
\% \\
\mathrm{H}_{3} \mathrm{PO}_{4}\end{array}$ & $\begin{array}{c}\mathrm{Mv} \\
\mathbf{1 0 3} \\
\boldsymbol{g} \cdot \mathbf{m o l} \\
\mathrm{H}_{3} \mathrm{PO}_{4}\end{array}$ \\
\hline 1 & 30 & 82.5 & 717 & 91.1 & 109 \\
& 40 & 82.7 & 677 & 91.6 & 251 \\
& 50 & 83.7 & 596 & 91.7 & 309 \\
\hline 2 & 30 & 84.4 & 586 & 93.7 & 324 \\
& 40 & 88.2 & 568 & 93.8 & 333 \\
& 50 & 89.3 & 554 & 94.0 & 356 \\
\hline 3 & 30 & 89.6 & 401 & 94.3 & 506 \\
& 40 & 89.8 & 350 & 94.7 & 515 \\
& 50 & 89.8 & 332 & 95 & 522 \\
\hline
\end{tabular}

In the same table it is observed that the demineralized chitosans with the phosphoric acid contain a higher percentage of residual inorganic material compared to the chitosan obtained from the $\mathrm{N}$-deacetylation of the demineralized chitins with the hydrochloric acid, which may explain the increasing behavior without pattern apparent molecular weight, since the residual ash, specifically calcium, can affect the solubility, and influence the viscosity of the same, and therefore, in the calculated molecular weight [31].

Table 5 shows the results of ash percentage, humidity, degree of deacetylation and molecular mass for commercial chitosan and the chitosan obtained in this work.

Table 5. Characteristics of experimentally and commercially obtained chitosan.

\begin{tabular}{|l|c|c|c|c|}
\hline Sample & $\begin{array}{c}\text { Ash } \\
\text { \% }\end{array}$ & $\begin{array}{c}\text { Humidity } \\
\text { \% }\end{array}$ & $\begin{array}{c}\text { DDA } \\
\text { \% }\end{array}$ & $\begin{array}{c}\text { MV } \\
\mathbf{1 0 - 3} \\
\mathbf{g} \cdot \mathbf{m o l}-\mathbf{1}\end{array}$ \\
\hline $\mathrm{HCl}$ & 1.99 & 8.4 & 89.3 & 553.9 \\
\hline${\mathrm{H} 3 \mathrm{PO}_{4}}^{\text {Pronova }} \begin{array}{l}\text { Biopolymer } \\
\text { industrial } \\
\text { grade }\end{array}$ & 5.50 & 7.6 & 95.0 & 522.1 \\
\hline $\begin{array}{l}\text { Qingdao } \\
\text { Develop } \\
\text { Chemistry } \\
\text { grade } \\
\text { agriculture }\end{array}$ & 2.5 & 13.1 & $\geq 85$ & - \\
\hline $\begin{array}{l}\text { Sigma- } \\
\text { Aldrich } \\
\text { HMW }\end{array}$ & 0.48 & 11.7 & 79.0 & $140-220$ \\
\hline $\begin{array}{l}\text { Sigma- } \\
\text { Aldrich } \\
\text { MMW }\end{array}$ & 0.61 & 13.7 & 81.4 & $110-150$ \\
\hline
\end{tabular}

It is appreciated that the value of ashes obtained experimentally is superior with respect to the commercial samples, this result depends to a large extent on the origin, properties and conditions in the obtaining of the chitosan. Taking into account the presence of inorganic materials in the chitosan samples, with respect to the reference ones, these results can be justified. The moisture content obtained is lower than that reported (Table 6). The loss of water in the sample is due to physical and chemical processes during the stage of obtaining the chitosan. During grinding, the removal of water content from hydrates results from localized frictional heating. The elimination of acetyl groups is also considered as a result of the thermoalkaline deacetylation of chitin that generates free amino groups in the polymer chain and is a site sensitive to the formation of hydrogen bonds with the oxygen of free radicals - $\mathrm{OH}$ and since the degree of deacetylation of the chitosans obtained from demineralized chitin with hydrochloric acid and phosphoric acid were 89.34 and $95.01 \%$ respectively, the possibility of formation of water molecules decreases due to a lower presence of amino groups.

Molecular masses superior to commercial samples were obtained. This is probably due to the treatment used for the deacetylation of chitin, very extreme treatments can break the chains of the polymer and decrease its molecular mass, on the other hand, depending on the crustacean species used, different varieties of chitin can be obtained, the high masses found that both chitin isolation and purification conditions and chitosan production preserved an original polysaccharide structure [32,33].

The chitosans obtained from deacetylation of the deproteinized chitins in the industrial reactor $(5,000 \mathrm{~kg})$ for three hours showed molecular masses of $68,000 \mathrm{~g} \cdot \mathrm{mol}-1$ for the demineralized ones with phosphoric acid (3M) and 110,000 g • mol-1 for demineralized with hydrochloric acid (2M). This result indicates that a time greater than 2 hours in deproteinization degrades the molecule and have lower molecular weights. In addition, with molecules of lower molecular mass, phosphoric acid is obtained. However, if more concentrated hydrochloric acid ( $3 \mathrm{M}$ ) is used, this ratio changes and the molecular mass decreases appreciably.

Deproteinization-demineralization by lactic acid:

The results for this step show that sugar turned out to be effective as a carbon source instead of molasses for the proper growth of lactic acid bacteria and the production of lactic acid, evidencing a decrease in $\mathrm{pH}$ and an increase in \% ATT.

The lactic fermentation depends largely on the carbon source and the concentration of it to obtain chitin. By increasing the fermentation time of 2 to 3 weeks, the removal of minerals in the shell increases, giving a $2.68 \%$ percentage of ash in the chitin obtained.

\section{CONCLUSIONS}

It was possible to obtain chitosan from crab exoskeletons of the variety Callinectes sapidus, with an average yield of $11.29 \%$, depending on the reaction conditions used.

The chitins and chitosans were characterized by infrared spectrometry with Fourier transform (FTIR).

The characterization of chitin and chitosan by the infrared spectroscopy method is based mainly on the comparison of the 
spectra related to the presence or absence of the carbonyl group and the acetyl radical.

The obtained chitosan presents the bands of the functional groups characteristic of this molecule.

The results indicate that demineralization with 2 molar hydrochloric acid, for a reaction time of 50 minutes, is the most suitable treatment for demineralization, since it considerably reduces the ash content in the obtained chitosan.

However, in terms of degree of deacetylation and molecular weight, the chitosans made with phosphoric acids showed a higher degree of deacetylation and the molecular weights were similar to those found with $\mathrm{HCl}$. The percentages of ash and humidity show that the purity of the chitosan obtained is acceptable, for food applications.

The main advantage of chemical treatment is the reaction time to obtain chitin. It is shorter compared to the biological method or fermentation. However, the extraction of chitin by lactic fermentation shows as advantages a greater waste management (whey and crab shells), although the extraction time of the final product is longer than with chemical treatment, it presents low costs, besides being environmentally friendly and in this process not only can chitin be obtained, but calcium lactate that can be recovered and subsequently used in the food industry for the fortification of beverages. Added to this, hydrochloric acid is a substance that is restricted by chemicals regulating agents, which makes it difficult to obtain and subsequently to apply in demineralization, making the biological method a viable and effective procedure for the extraction of chitin.

\section{REFERENCES}

[1] Manuscript Templates for Conference Proceedings, IEEE. http://www.ieee.org/conferences_events/conferences/publishing/templates .html

[2] M. King, B. Zhu, and S. Tang, “Optimal path planning,” Mobile Robots, vol. 8, no. 2, pp. 520-531, March 2001.

[3] H. Simpson, Dumb Robots, $3^{\text {rd }}$ ed., Springfield: UOS Press, 2004, pp.6-9.

[4] M. King and B. Zhu, "Gaming strategies," in Path Planning to the West, vol. II, S. Tang and M. King, Eds. Xian: Jiaoda Press, 1998, pp. 158-176.

[5] B. Simpson, et al, “Title of paper goes here if known,” unpublished.

[6] J.-G. Lu, "Title of paper with only the first word capitalized," J. Name Stand. Abbrev., in press.

[7] Y. Yorozu, M. Hirano, K. Oka, and Y. Tagawa, "Electron spectroscopy studies on magneto-optical media and plastic substrate interface," IEEE Translated J. Magn. Japan, vol. 2, pp. 740-741, August 1987 [Digest $9^{\text {th }}$ Annual Conf. Magnetics Japan, p. 301, 1982].

[8] M. Young, The Technical Writer's Handbook, Mill Valley, CA: University Science, 1989.

[9] Agüero G, Argüelles W, Peniche C "Estudio de la cristalinidad de la quitosana”, Revista Cubana de Química., 5(1), 25 (1989)

[10] Argüelles M, Gárciga C, Peniche W "Study of the stoichiometric polyelectrolyte complex between chitosan and carboxymethyl cellulose", Polymer Bull., 23, 307 (1990)

[11] Nieto JM, Peniche C, Padrón G “Characterization of chitosan by pyrolysismass spectrometry, thermal analysis and differential scanning calorimetry”, Thermochimica Acta, 176, 63 (1991)

[12] Peniche C, Alvarez L, Argüelles W "The adsorption of mercuric ions by chitosan”, J. Appl. Polym. Sci., 42, 1147 (1992)

[13] Argüelles W, Peniche C "Preparation and characterization of a mercaptan derivative of chitosan for the removal of mercury from brines", Die Angewandte Makromol. Chemie., 207, 1 (1993)

[14] Nieto JM, Peniche CJ "Preparation and characterization of a chitosanFe(III) complex”, Carbohydrate Polymers, 18, 221 (1992)
[15] Peniche C, Argüelles J “A kinetic study of the thermal degradation of Chitosan and a mercaptan derivative of chitosan”, Polymer Degradation and Stability, 39, 21 (1993)

[16] Brugnerotto J, Lizardib J “An infrared investigation in relation with chitin and chitosan characterization”, Polymer, 42, 3569 (2001)

[17] Solomon OF, Ciutâ IZ "Détermination de la viscosité intrinsèque de solutions de polymères par une simple détermination de la viscosité”, $J$. Appl. Polym. Sci., 24, 683-686 (1962)

[18] AOAC (Association of Official Analytical Chemists), 2005, Official Methods of Analysis, Methods 925.10 Humedad, 18th Edition, USA, Cap., 4, 33-36.

[19] AOAC (Association of Official Analytical Chemists), 1990, Official Methods of Analysis, Methods 923.03 Cenizas, 16th Edition, USA, Cap., 4, 40-42.

[20] Stover R, Simmonds N “Bananas”. Longman scientific and technical. Third edition. England, 1987

[21] López Adriana “Obtención de derivados de almidón y quitosano a partir de materias primas y desechos sólidos industriales”. Tesis Doctoral. Facultad Experimental de Ciencias. Departamento de Química. Universidad del Zulia. Maracaibo. Venezuela, 2012

[22] Majeti NV, Ravi K “A review of chitin and chitosan applications”, Reactive \& Functional Polymers, 46, 1 (2000)

[23] Wang QZ, Chen XG, Liu N, Wang SX, Liu CS, Meng XH, Liu CG "Protonation constants of chitosan with different molecular weight and degree of deacetylation”, Carbohydrate Polymers, 65, 194 (2006)

[24] Vielma A “Evaluación del proceso de decoloración de los caparazones de cangrejos provenientes de la Industria cangrejera”. Trabajo Especial de Grado. Facultad de Ingenieria. Universidad Rafael Urdaneta. Maracaibo. Venezuela 2010

[25] Youn DK, No HK Prinyawiwatkul W "Physicochemical and functional properties of chitosans affected by sun drying time during decoloration”, LWT Food Science and Technology, 42, 1553 (2009)

[26] Chaussard, G.; Domard, A., 2004,“New Aspects of the Extraction of Chitin from squid Pens”, Biomacromolecules., 5, 559-564.

[27] Donard A "Physicochemical properties of chitinuous materials", Advances in chitin science, 3, 24 (1989)

[28] Hasegawa M, Isogai A, Onabe F "Preparation of low-molecular-weight chitosan using phosphoric acid”, Carbohydrate Polymers, 20, 279 (1993)

[29] Aranaz, I.; Mengíbar, M.; Harris, R.; Paños, I.; Miralles, B.; Acosta, N.; Galed, G.; Heras, Á., 2009, "Functional Characterization of Chitin and Chitosan”, Current Chemical Biology, 3, 203-230

[30] Fernández, C.; Ausar, S.; Badini, R.; Castagna, L.; Bianco, I.; Beltramo, D., 2003, “An FTIR spectroscopy study of the interaction between $\alpha$ scasein-bound phosphoryl groups and chitosan”, International Dairy Journal., 13, 897-901.

[31] Pillai CK, Paul W, Sharma CP "Chitin and chitosan polymers: Chemistry, solubility and fiber formation”, Progress in Polymer Science, 34, 641 (2009). 